\title{
Stone wood and metal in the memorial sculpture of Ukrainian historical cemeteries of the Polish-Ukrainian borderlands
}

\author{
Olena Stasyuk \\ olena.stasyuk@gmail.com \\ Department of Architecture and Restration, Fakulty of Architecture, \\ National University "Lviv Polytechnic», Ukraine
}

\begin{abstract}
The memorial sculpture of Ukrainian historical cemeteries of the Polish-Ukrainian borderlands was analyzed. The existing state of objects is characterized. Use and preservation of materials - stone wood and metal - from which the typical models of the memorial imagery are executed was investigated. Special attention is paid to the discovery and research of unique samples of the memorial plastics made of different materials which were discovered during field works.
\end{abstract}

Keywords: historic cemetery Polish-Ukrainian borderlands, memorial sculpture, monument, stone, wood, metal.

\section{Introduction}

Memorial imagery ia a significant element of the material cultural heritage of the borderlands. This includes roadside crosses and figures, small architectural forms. But the most striking objects are architectural ensembles of historical cemeteries - Catholic, Greek Catholic, Protestant, and Jewish. The history has developed in such a way that it was Ukrainian cemeteries on the borderlands that remained inconsumable deprived of care, lost in the forests because they lacked real owners. However, they are witnesses of history and museums open-air lapidary.

Many researchers of both Ukrainian and Polrnd were interested in the memorial imagery of the borderland. In particular, the Museum of Crests in Lubachiv has published a book devoted to Brusno masonry, the lion's share of which is the memorial imagery [1]. The materials of our field studies of the borderlands cemeteries were published in newsletters and collections of scientific works of the Lviv Polytechnic National University [2, 3]. In 2012, a book by Tomasz Cervinski dedicated to chapels and roadside crosses in Poland was published in Warsaw. The book explores the symbolism, assembles a huge factual and illustrative base from all over Poland, and the objects themselves are divided and analyzed by materials. [4]. Extremely interesting and valuable work of Polish researchers is dedicated to the inventory of Lemko cemeteries. [6] - rich and detailed photo fixation, a brief historical background, dimensional drawings. Another rich source of information about the Ukrainian historical cemeteries of the border is Internet resources, in particular Apokriff Russky [7].

\section{The material of the study}

The Brusno stone-masonry school froms most of the memorial imagery of the borderland on the territory from Krakow to Lviv. This is one of the most striking cultural phenomena of the Polish-Ukrainian borderland, which is the heritage of many generations of folk masters of stone masons from villages in the vicinity of the main stone-masonry centre in Old Brusno, Lyubacheeve region. In addition to stone such materials as wood and 
metal also form the memorial imagery of the borderland. Namely the cemeteries are the studying polygons of the memorial imagery. The cemeteries are very different - in size (that is, in area), in saturation (the number of monuments - from several dozens to several hundreds), in quality (how interesting and various monuments are present at a particular cemetery) and, finally, on natural factors ( what vegetation, presence or absence of water, etc.). In this case, when we are talking about quantity or quality, we are talking about the assessment on the day of today, that is, we are oriented only on the preserved monuments. The last factor, that is natural, directly affects the preservation of the physical substance of the tomb memorials.

Historical cemeteries of the borderland are filled with monuments executed mainly of stone, namely, limestone. The oldest form of the tombstone is a simple cross. First, just a pure cross, without the inscriptions or drawings, and later with cut inscriptions, dates or solar signs. Such a cross was mounted on the base of an incorrect, irregular shape, similar to a stone simply pulled out of the river, somewhat hemmed with water. These ancient crosses are usually very well preserved. They are executed though from a porous but strong stone. And already in these first crosses a technical model was laid - a method of mounting tombstones. This is a way of a peculiar designer «lock»-a «nest», without any glue, solution or sealant. Over time, the number of elements of the composition increased, but the method remained the same. The most common type of monument is the cross with the figure of the crucified Jesus Christ on a simple square in the plan-base and a cross with the figure of the crucified Jesus Christ and coming sometimes on a complicated, well-developed basis with a high base and a pillar. In this case, the composition consists of three parts. There is the most of such monuments, they can be found at every cemetery. Sometimes, but very rarely, there are figures. The most popular motive is the Mother of God. Sometimes with a child Jesus on her hands. Much less often is a male figure like Jesus Christ, Nicholas, or the image of an angel.

The state of preservation of the physical substance of stone depends primarily on the quality of the stone itself. It happens that if the stone is of poor quality then it can slip like a French dough. Unfortunately, such a state of stone is practically not subject to renovation or restoration. The next factor that greatly affects on the preservation and strength of the stone is a natural factor. It is he who decides how much the stone is covered with moss, fungi and other biological pests, that is, how quickly the stone will be destroyed. Here, we can count the roots of trees, which is very relevant in the case of a cemetery found in the forest and which is unused. The last factor, but no less harmful is human activity. The drawing of a stone is a complicated and ambiguous procedure. Very often we see that it is precisely this kind of activity that causes the destruction, scattering of stone. Various materials lead to such consequences - this is a thick layer of lime, oil paint, various chemical and synthetic paints, such as gilding, varnishes, and the like. Drawing a stone monument is decided by a specialist-restorer in each particular case - whether it is possible and necessarily. Cleaning or gluing with incorrect materials leads to similar negative consequences.

For today, the state of preservation of the physical substance of the stone can be considered satisfactory. So there are a number of problems with biopsies and unprofessional ordering of objects, but in the general stone is strong, well-worked and set, inscriptions and decorative elements are expressive and readable.

Sometimes in some cemeteries you can see the remains of wooden crosses and other wooden structures - it's mostly a variety of fences and railings. There are no wooden objects at all in many cemeteries, such as New and Old Brusno, Goraytsy, Zhukov, Lyubichi Korolevska and Kameralna, Prince, Podemshiny. Perhaps the tree served as an element of the fence of the cemetery itself, as some objects preserved stone fences with characteristic nests in which pledged wooden elements were mounted. But such designs are not preserved.

On the other hand, some wooden crosses can be found in the territory of some cemeteries, for example in villages or in former villages of Tsityl (Fig. 1), Dobra (Fig. 2), Dubrovitsa, Chervona Volya. Such crosses are usually very simple. These, so-called Latin crosses are made of plains, square in the section of boards. Sometimes a cross-section of the cross contained a small wooden or metal plate for the inscription. Still, more often than not, this is simply a cross without any decor, ornaments and the inability to identify who is buried there.

The cemetery in the former village of Sukha Wola, which we researched during one of the expeditions, turned my view of wooden crosses. There are not so many in the cemetery. Some still firmly stand, some have already bent (Fig. 3). During the cleaning of the cemetery, we occasionally stumbled upon the remains of wooden crosses, which clearly indicated that such crosses were much larger, but they simply did not physically survive until our time. So the crosses that were located at the beginning of the cemetery were Latin, traditionally quite simple in shape, made of plains, square in the section of boards. 


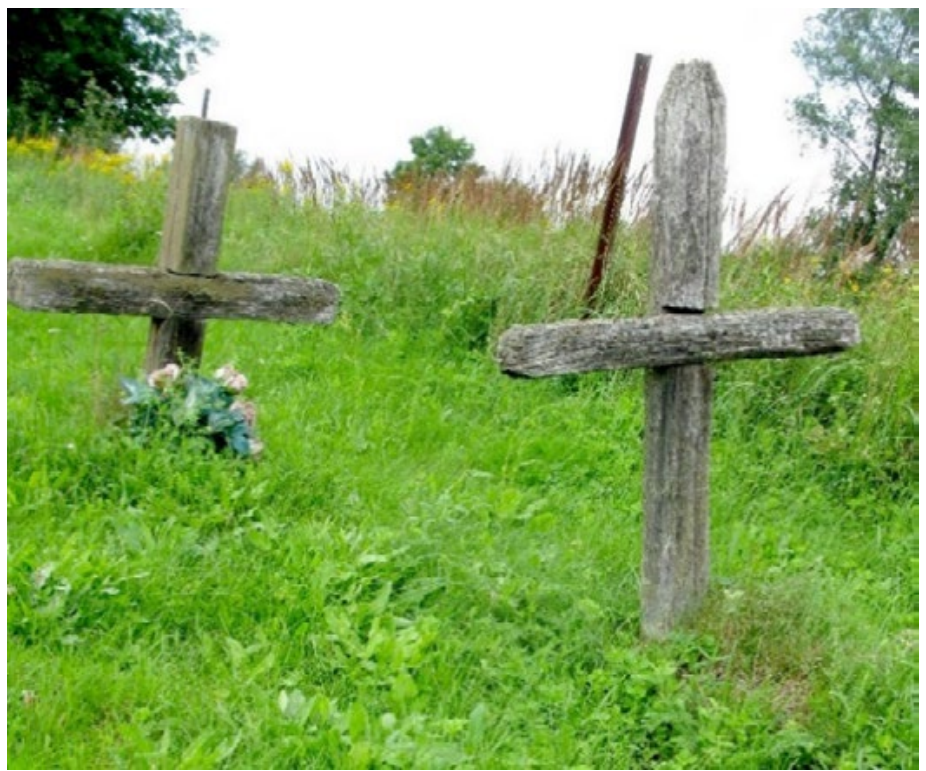

Fig. 1. Wooden crosses at the cemetery in the village. Citation

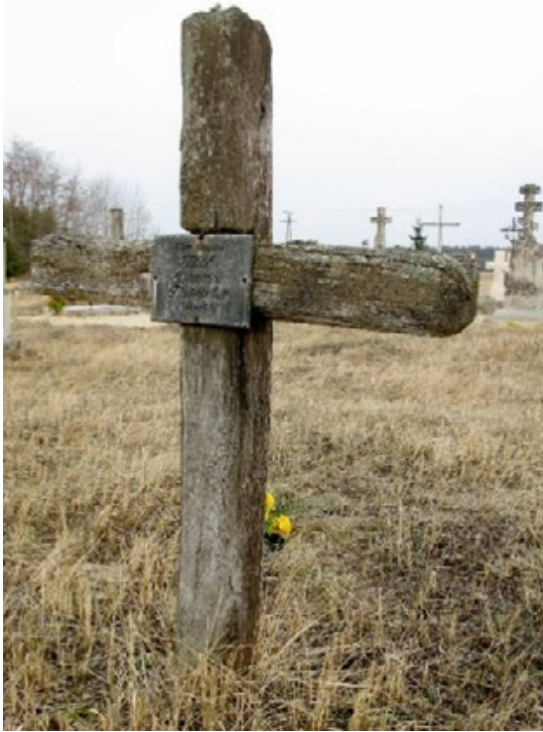

Fig. 2. Wooden crosses at the cemetery in the village. Good

The raams of the crosses ended with decorative bullets, and the bodies were covered with inscriptions. These inscriptions are engraved on a tree and are arranged in different ways - along, across, diagonally. The font of the inscriptions is correct and professional, and the work is executed skillfully. Some crosses have niches made of rectangular, circular or oval shapes, possibly for insertion of a photo, or maybe icons.

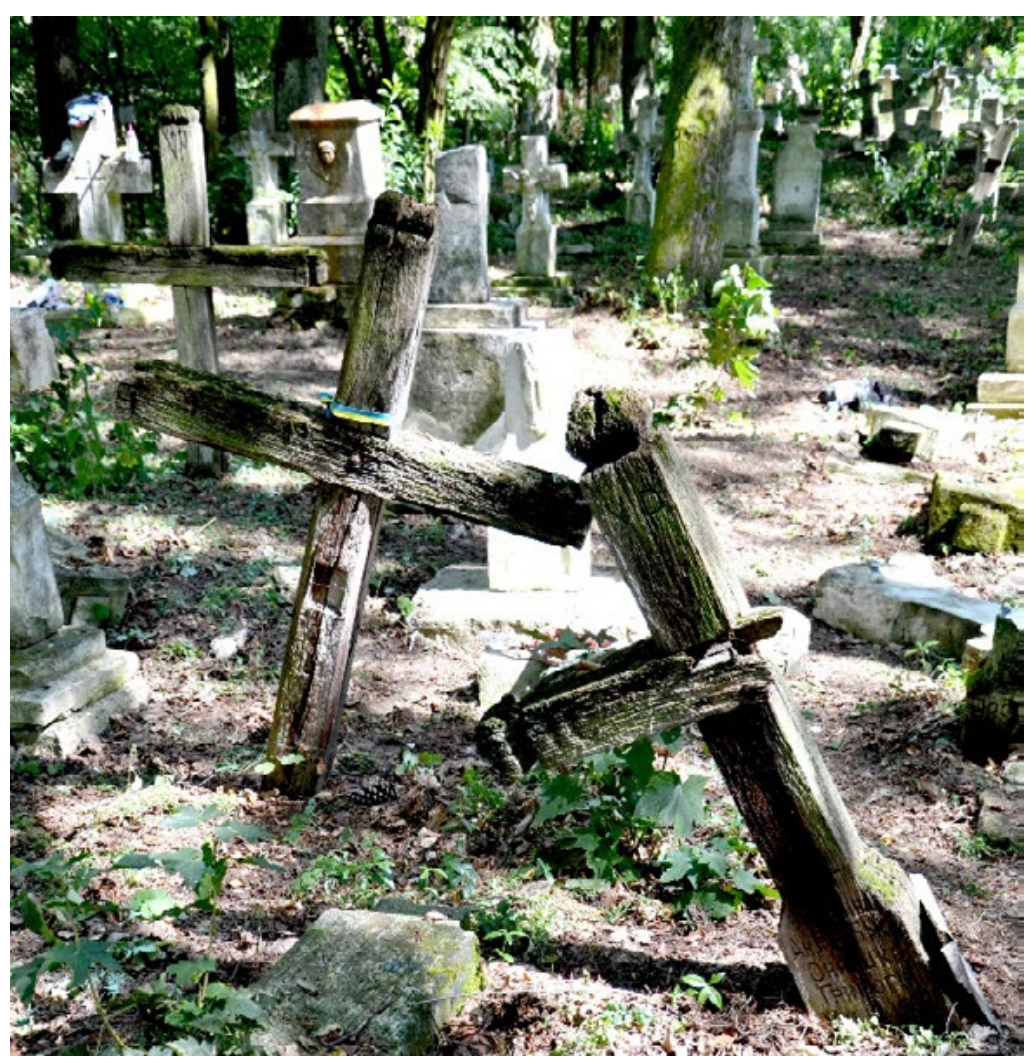

Fig. 3. Wooden crosses at the cemetery in the former village Sukha Volya 
But the greatest impression was made by the great but very destroyed wooden cross that lay on the ground and was hidden between the grass, the leaves and branches were falling off. In form, this cross is an exact copy of a traditional stone cross on a complex built-up basis with a high base and a pillar of a stone. Not enough just crucifixion. The construction of the pillar carries a classic architectural character - it is completed with a traditionally profiled cornice crowned crown with teeth. In this case, these teeth are semi-circular. The teeth may be sharper or smoother, they may be different amounts depending on the size of the object. On the front side of the pillar practically for all its width niche with arch completion is carved. Such niches, at least in stone monuments, were intended for inscriptions. But in this case the tree is very destroyed. The lower part of this cross is very destroyed and partially lost so it is impossible to understand how and where it was installed and how it was attached to the base. (4)

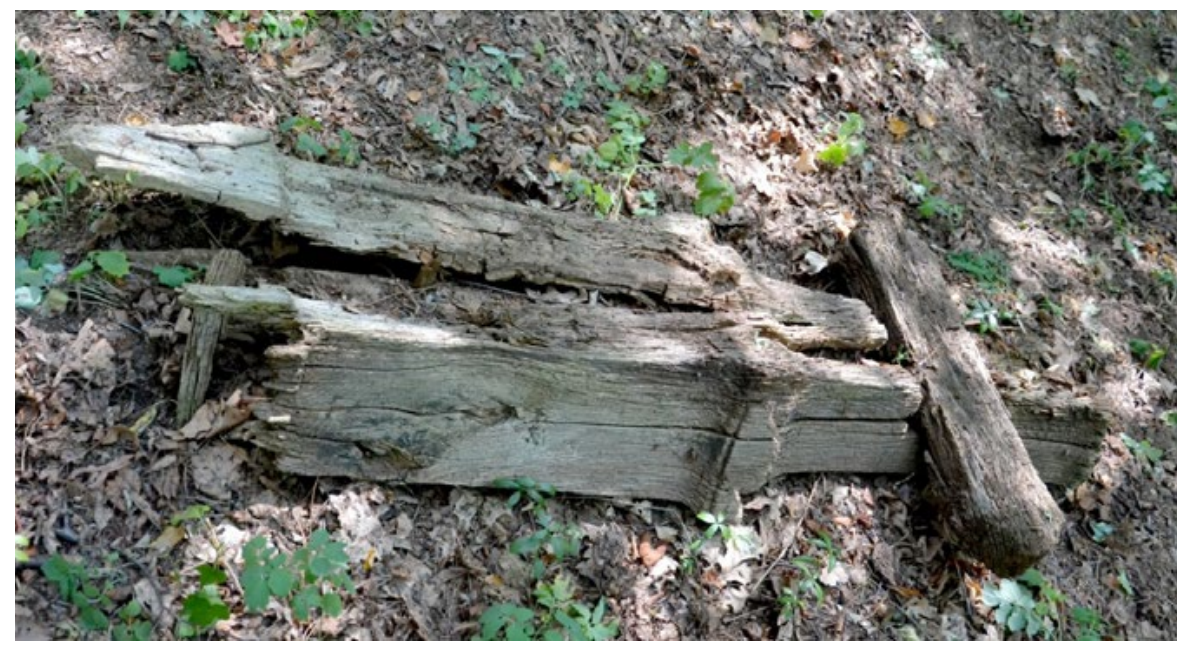

Fig. 4. Cross at the cemetery in the former village Sukha Volya

For comparison, here are two stone tombstones with the same compositional structure and construction, as in a wooden cross from former village Sukha Volya (puc. 5,6). There are much more of such examples, and several can be found on the each cemetery. The given examples are different in proportions, there is a richer and more modest profile of cornices, a different form of completion of a niche on the front side of the pillar. The cross that crouches the composition once is a crucifix, and once without. That is, there is always a place for creativity for the author of the art work, but composite models are preserved.

And the technological aspect of building these monuments deserves attention. Stone monuments were always executed from several parts and these parts were mounted one to another without glue. A vertical cross made from one piece of wood. Even if a piece of wood is not one, then the integrity is mounted firmly and is perceived as one continuous fragment. The transverse plate is mounted, that is, the arms of the cross. They are executed from another piece of wood. In this part the master does not try to create the impression of integrity, but all the details are still mounted tightly. While parts of the stone monument are easily disassembled and collected together.

Another material that can be found on some of the cemeteries is metal. It can be forged metal as a grille or fence. This can also be cast iron casting. In the Local Lore museum in Lubachiv they claimed that that on these lands there was a widely developed blacksmithing. However, we never meet the crosses of blacksmithing work at the cemetery of borderlands On some cemeteries you can find samples of cast-iron cast crosses. The cast iron cross is mounted on a stone base of various sizes and shapes. Such cast products were distributed in eastern Europe from the second half of the $19^{\text {th }}$ century till the thirties of the $20^{\text {th }}$ century. [7]. Cast-crosses were a mass production that grew rapidly. Particularly widespread such products were in metallurgical areas where the cemeteries can be seen just like a castle cross forest. There were catalogs of cast-iron products, in particular, tomb crosses [8]. Cast iron casting was quite diverse, rich in ornamentation and dynamic (it allowed the use of the same parts in different compositions). Cast iron casting listened to the customers' tastes. End of 19 - the beginning of the $20^{\text {th }}$ century. it was a time of neo - styles and the most popular were Gothic, Renaissance and Baroque motifs. 


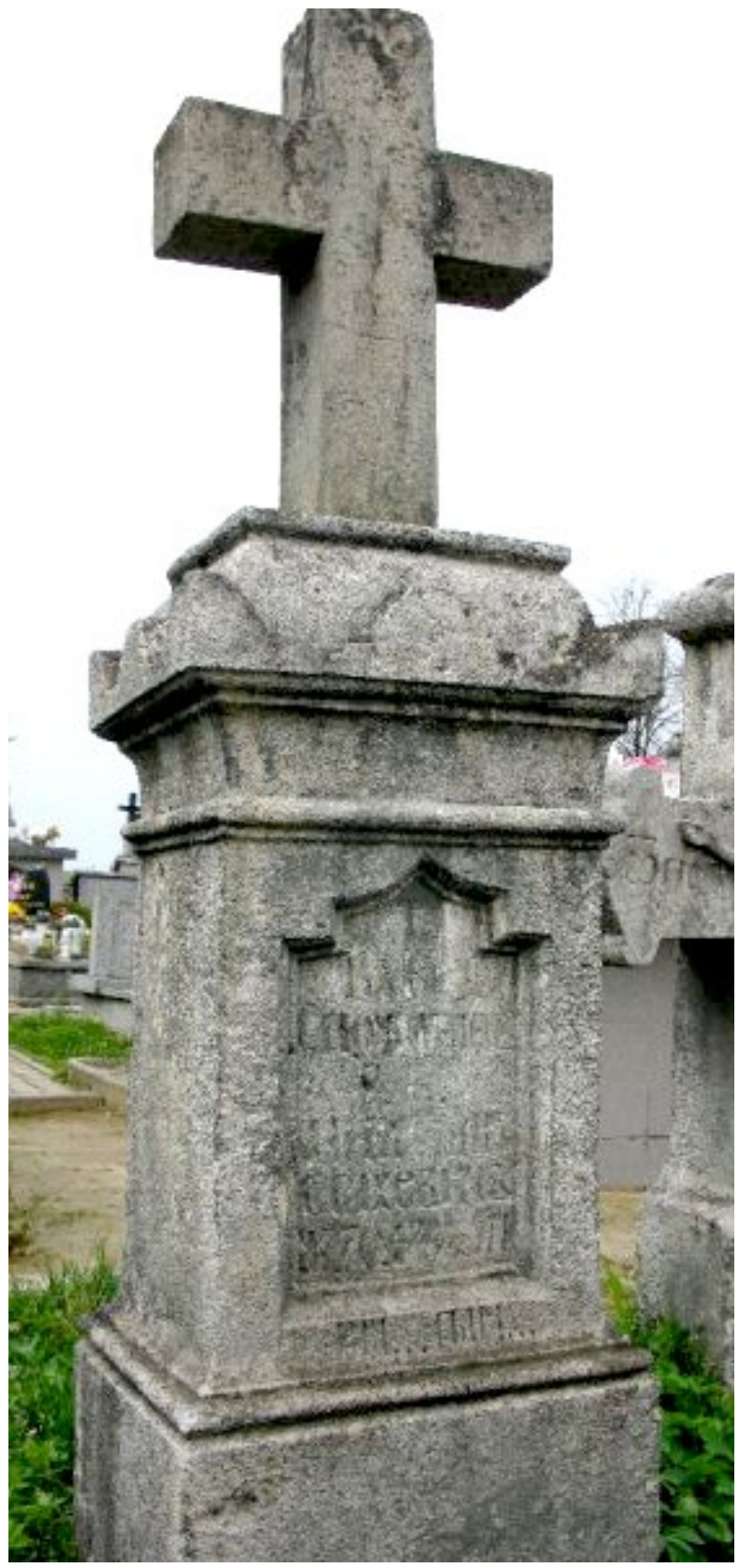

Fig. 5. Cross at the cemetery in the village Oleshucia

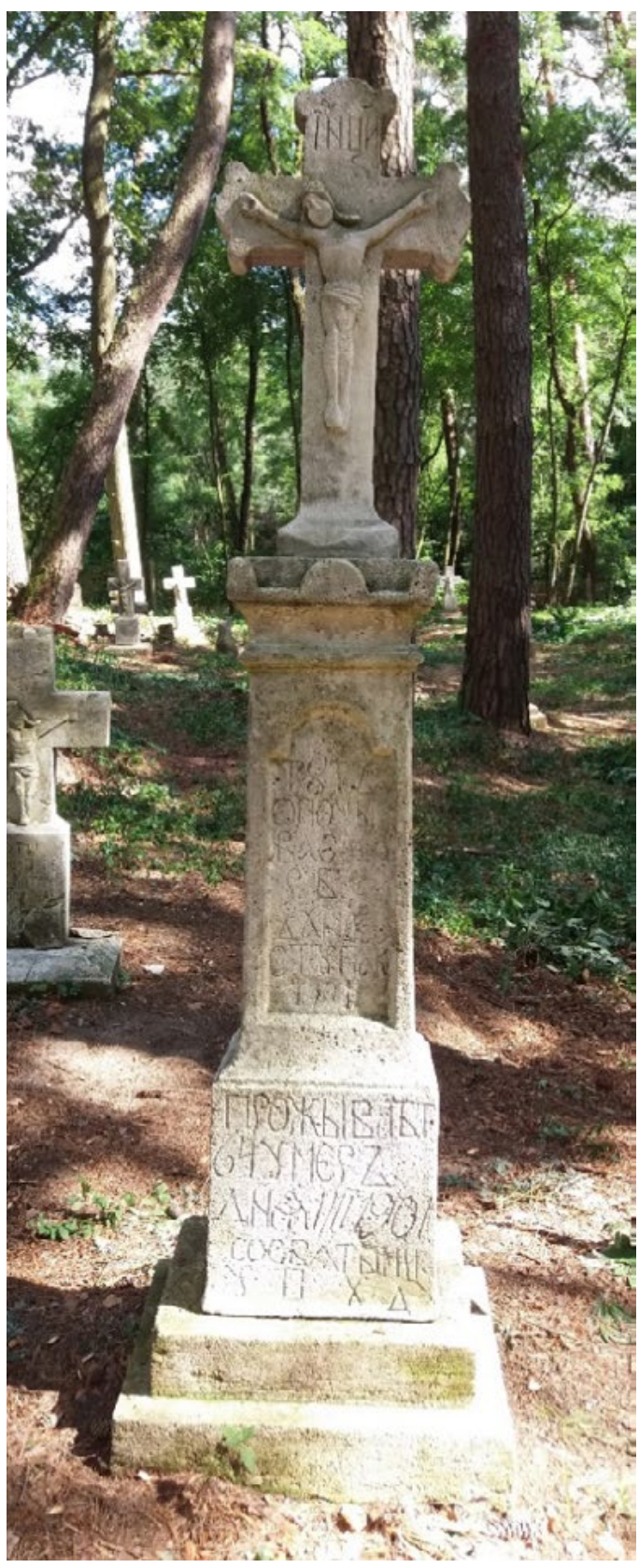

Fig. 6. Cross at the cemetery in the former village Sukha Volya

There are not many cast iron crosses in the cemeteries of the Ukrainian-Polish borderlands. For example, in the cemeteries in Novyi and Old Brusno, Goraitsy, there is not a single metal cross, in Sukhya Volya one, in Zhukov two. Other Ukrainian cemeteries of borderlands. have a similar situation. Cast iron crosses we we met were, as a rule, with baroque motifs. Concerning preservation - it is different and depends primarily on the quality of the metal itself and the casting. There are cases when metal is in excellent condition, it happens when the metal is very rusty and destroys the stone with which it coexists. There are cases when the metal is brittle and easily broken. During the studies of the borderland cemeteries, we often encountered fractures of cast iron crosses, perhaps even more often than the surviving objects. And we have never met cases of the repairing or restoration of cast-iron objects (for example, gluing, welding, etc.). 
As has already been said about serial production - tombstones are ordered by catalog. The same crosses can be seen at the cemetery in Prague, Krakow, Lviv, Przemysl or Lubachiv, as well as in the cemetery of the non-existent already village in Lemkiv mountains. This is the motive of the cross with the crucifixion and the coming with Baroque motives. In this Lemkiv village in the mountains, they made something unique and special. An exact copy of a cast-iron cast cross with baroque motifs - with figures of upcoming, angels - was cut from a stone. The composition, the posture and movement of the figures, the folds of clothing - is identical Make such a thing is not very easy. The author of this monument is unknown, but it was to be a skilful and professional sculptor. The monument is located in Volosate, a former Lemko village, and now the official settlement of the Beskydy National Park in Poland.

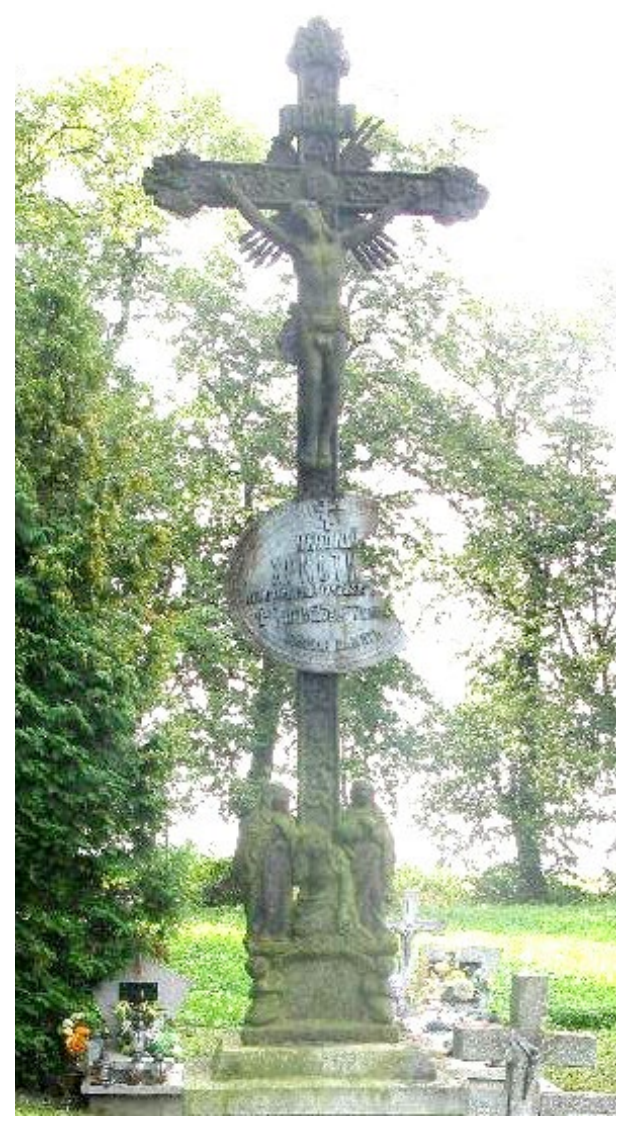

Fig. 7. Cross at the cemetery in the village Drohojiw

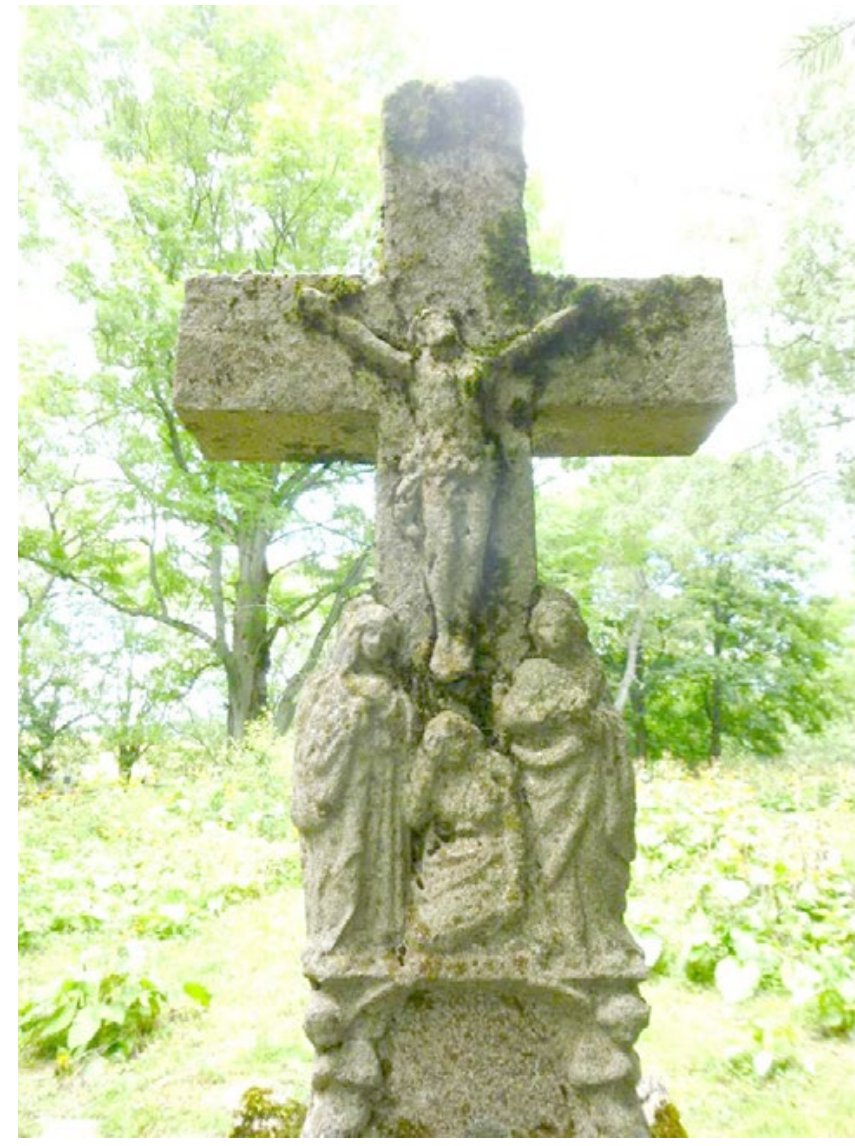

Fig. 8. Cross at the cemetery in the village Volosate

\section{General conclusions}

Wood stone and metal on the Ukrainian historical cemeteries of the polish-ukrainian borderlands exist in parallel. Because of the physical properties of the material (the wood is destroyed the fastest, the metal serves longer and the most stable is the stone). Wooden monuments have survived very little and they are dated 30 years of the twentieth century. The metal also remained a bit, but the older objects are of better quality and preserved better than the later. The stone was and remained in the dominant position on the cemetery. There are no examples when the wood and a stone were used together in one tombstone. Instead, metal has always been combined with stone.

The nature of the material dictates the style of the product made in this material, his artistic techniques and features. Two unique examples are presented when trying to make a copy of another material in one material. 
The first is when wooden monument repeat stylistically, and actually copy the stone model. I do not think that such a monument was truly unique, but at the moment it is the only surviving example that we have been able to find. Moreover, the wood collapses just before the eyes - it breaks down, drain down, rubbing, and requires conservation and preservation. The second is when stone monuments repeat stylistically, and actually copying the cast iron model. I do not know if such a monument was truly unique, but at the moment it is the only surviving example that we have been able to find. The stone is in good condition, it does not threaten the rapid destruction.

Both examples are unique, at least because they are the only surviving examples. They are part of the history. And such examples deserve not only fixation, but also restoration and preservation. The traditional stone carving of the Brusno stone-masonry school is evidence of the uniqueness and features of the region where it was born. Cast iron crosses of ukrainian historical cemeteries of the polish-ukrainian borderlands is evidence that Europe was united already in the $19^{\text {th }}$ century. Experiments with traditions and materials - wood, stone and metal - testify to the fact that we are constantly moving, changing, looking forward and building something new.

\section{References}

[1] Kresowe dziedzictwo. Kamieniarstwo bruśnieńskie. Tekst Jannusz Mazur. - Muzeun Kresów w Lubaczowie. - Liubaczów, 2008. - S. 130.

[2] Remeshilo-ribchinska O., Stasyuk O. Features of revalorisation of Lyubachiv cemeteries ensembles with the memorial plastic «Brusno school» (for example, illage Zhukiv) // Bulletin of the Lviv Polytechnic National University, Architecture - №632. - Львів, 2008. - с.161-168.

[3] Stasyuk O. The phenomenon of the Brusno stone-masonry school in the context of the problem of studying the conservation and restoration of memorial monuments of the historical cemeteries of Lyubachiv region // Collection of Scientific Papers of the RRAC Chair of Lviv Polytechnic National University - Lviv,2014. - c.277-283. -

[4] Czerwiński T. Kapliczki I krzyże przydrożne w Polsce. - Warszawa, Sport I turystyka, 2012 - - 378 s.

[5] Dubec R., Janczy A. Inwentaryzacja cmentarzy łemkowskich na terenie gminy Sękowa. Tom I - Gorlice, 2008. - $296 \mathrm{~s}$.

[6] http://www.apokryfruski.org

[7] Herain, Kare Umělecké práce z litany. Katalog výstavy umĕleckých praci z litany. Záři - řijen 1933. Praha1933. - Výstavu pořádalo Umĕlecko - průmyslové museum v Praze.

[8] Anonymni vzorniky z Muzea Českého krasu Beroun z r. 1871. 